\section{Primeros hallazgos \\ del Estudio sobre hermanas*}

Erin E. Dooley

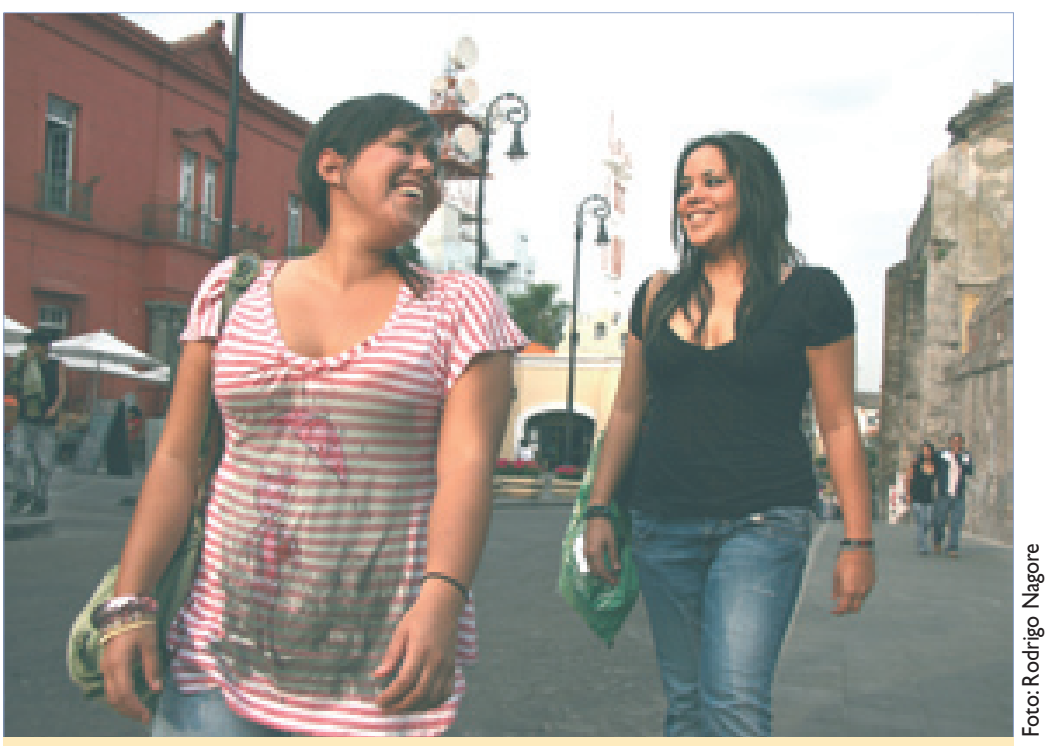

El Estudio sobre hermanas incluye a mujeres cuya hermana tuvo cáncer de mama.
L os primeros hallazgos del Estudio sobre hermanas patrocinado por el National Institute of Enviromental Health Sciences (NIEHS), que se publicaron en los números de Cancer Epidemiology Biomarkers \& Prevention de febrero y marzo de 2009, demostraron que las mujeres que mantenían un peso saludable y se percibían a sí mismas como menos estresadas tendían menos a tener telómeros cortos; los telómeros son las secuencias repetitivas de $\mathrm{ADN}$ que protegen los extremos de los cromosomas y ayudan a mantener la integridad genética durante la replicación celular. Los telómeros acortados se asocian con un mayor riesgo de enfermedad y con un incremento de los índices de mortalidad por cáncer y enfermedad del corazón. Estos reportes se agregan a investigaciones anteriores que demuestran que los cambios positivos de estilo de vida pueden promover la actividad telomérica.

* Publicado originalmente en Environmental Health Perspectives, volumen 117, número 5, mayo 2009, página A196.

\title{
La vitamina D regula el gen de la esclerosis múltiple*
}

\section{Carol Potera}

S

e piensa que la esclerosis múltiple (EM), una enfermedad autoinmune que afecta a 2.5 millones de personas en todo el mundo, surge de una confluencia de factores genéticos y ambientales. Se ha asociado la ingesta alimentaria de vitamina $\mathrm{D}$ con menores riesgos de
EM, y se ha asociado la deficiencia de vitamina $D$ con el incremento del riesgo, pero no se han establecido vínculos entre la vitamina $\mathrm{D}$ y la $\mathrm{EM}$. Un equipo de investigadores canadienses y británicos ha reportado ahora evidencias de que la vitamina D interactúa con una forma variante del gen HLA-DRB1, que ha sido asociado a la EM.

Como se reportó en el número del 6 de febrero de 2009 de la revista en línea PLoS Genetics, el director del estudio, George Ebers, un neurólogo clínico de la Universidad de Oxford, Reino Unido, y sus colegas

\footnotetext{
* Publicado originalmente en Environmental Health Perspectives, volumen 117, número 5, mayo 2009, página A196.
} 
examinaron células con dos copias de la forma HLA-DRB 15 del HLA$D R B 1$. Identificaron un elemento de respuesta a la vitamina D (ERVD) -un tramo corto de ADN que es una rúbrica de los genes regulados por la vitamina D- al lado del gen. Cuando examinaron ADN de los participantes del estudio, encontraron la misma secuencia de ERVD en cada uno de los 322 individuos con dos copias del HLA-DRB1*15 (incluyendo a personas con y sin EM), pero encontraron secuencias de ERVD diferentes en las muestras de ADN de 168 participantes del estudio sin HLA-DRB1*15. Los investigadores también demostraron que la secuencia de ERVD encontrada en las personas con HLA-DRB1*15 podía ligarse al receptor de vitamina $\mathrm{D}$, y que el gen respondía con mayor intensidad a la vitamina $D$ en células con la secuencia $H L A-D R B 1^{\star} 15$ ERVD que en células que carecían de ésta.

"Esta es la primera evidencia directa de que la vitamina $\mathrm{D}$ regula el gen", dice Ebers. Señala que, mientras que el público en general tiene 1 posibilidad entre 1000 de desarrollar EM, el riesgo estimado de EM es de 1 por cada 300 personas con una copia de la variante $H L A-D R B 1^{*} 1501$ del gen y de 1 por cada 100 en aquellos que tienen dos copias del HLA$D R B 1^{*} 1501$. El siguiente paso consiste en determinar de qué manera pueden interactuar la vitamina $\mathrm{D} y$ el HLA-DRB1*1501 para modular la naturaleza autoinmune de la EM. Los estudios epidemiológicos y los estudios en animales sobre la EM apuntan hacia la participación de la glándula del timo en las etapas tempranas de desarrollo. El timo produce células T, un tipo de glóbulos blancos que intervienen en las respuestas inmunes a proteínas extrañas (antígenos). Cada célula T está hecha con un receptor de antígenos único que permite al sistema inmune reaccionar rápidamente a cualquier proteína extraña con la que se pueda encontrar una persona. Sin embargo, las células T con receptores de antígenos que pudieran responder a las proteínas normales "propias" deben ser destruidas para prevenir una respuesta autoinmune. Los investigadores razonan que una falta de vitamina $D$ en el timo en las etapas tempranas de la vida podría limitar este proceso, permitiendo a las células T "autodirigidas" sobreviviry provocar una respuesta autoinmune a las vainas de mielina que recubren las fibras nerviosas, un rasgo característico de la EM.

Los autores proponen que la ingesta de suplementos de vitamina $\mathrm{D}$ en los periodos críticos durante el embarazo y en la infancia puede reducir el riesgo de desarrollar EM, opinión refrendada por Bruce Hollis, un bioquímico de la nutrición y profesor de pediatría de la Universidad de Medicina de Carolina del Sur. Mientras que el Instituto de Medicina recomienda ingerir 200 unidades internacionales de vitamina $\mathrm{D}$ al día (UI/día) para las personas menores de 50 años, incluyendo a mujeres embarazadas y en periodo de lactancia y bebés, Hollis escribió en el número del Journal of Bone and Mineral Research de diciem- bre de 2007 que podrían necesitarse hasta $6000 \mathrm{UI} /$ día para mantener los niveles adecuados de esta vitamina en la sangre para estas poblaciones. Actualmente está concluyendo una investigación financiada por los Institutos Nacionales de Salud de EUA que sugiere que una ingesta óptima sería de por lo menos 2000 UI/ día. [Para más información sobre la deficiencia de vitamina $B$, véase "Benefits of sunlight: A bright spot for human health", EHP 116:A160-A167 (2008)].

"Muchos obstetras se olvidan de los niveles de vitamina $\mathrm{D}$ de sus pacientes y suponen erróneamente que la minúscula cantidad de vitamina $\mathrm{D}$ que contienen las vitaminas prenatales bastará para satisfacer las necesidades de sus pacientes", dice Hollis. "De hecho, esa cantidad ni siquiera se acerca a la suficiente." Considerando que el cuerpo genera hasta 20000 UI de vitamina D cuando se lo expone a la luz del sol durante 30 minutos en un día de verano, Ebers dice que $2000 \mathrm{UI} /$ día "no es una cantidad peligrosa."

\title{
Nutrientes protectores contra la toxicidad del arsénico*
}

\section{El folato y la cisteína apoyan la metilación en los niños}

\author{
Kris Freeman
}

$\mathrm{S}$ e sabe que ciertos factores nutricionales influyen en el metabolismo del arsénico en los adultos, y se considera que los niveles nutricionales bajos -reflejados en parte por la falta de varias de las vitaminas B y de antioxidantes- confieren una mayor susceptibilidad a la toxicidad por arsénico. Ahora algunos investigadores que laboran en Bangladesh han reportado que los déficits de folato y de vitamina B y del aminoácido cisteína pueden influir de manera adversa en el metabolismo

* Publicado originalmente en Environmental Health Perspectives, volumen 117, número 5, mayo 2009, página A211. 